\title{
Nowo rozpoznane nadciśnienie tętnicze u pacjentki w trakcie hormonoterapii anastrozolem z powodu raka gruczołu piersiowego
}

\section{New diagnosed hypertension in a patient during anastrozole hormone therapy due to breast cancer}

\author{
Joanna Latek-Książek ${ }^{1}$, Małgorzata Woźniak ${ }^{1}$, Elżbieta Piechocka ${ }^{1}$, \\ Robert J. Gil ${ }^{1,3}$, Aneta I. Gziut ${ }^{1}$ \\ ${ }^{1}$ Klinika Kardiologii Inwazyjnej Centralnego Szpitala Klinicznego Ministerstwa Spraw Wewnętrznych i Administracji w Warszawie \\ ${ }^{2}$ Zakład Diagnostyki Radiologicznej Centralnego Szpitala Klinicznego Ministerstwa Spraw Wewnętrznych i Administracji w Warszawie \\ ${ }^{3}$ Instytut Medycyny Doświadczalnej i Klinicznej Polskiej Akademii Nauk w Warszawie
}

\section{Streszczenie}

Przedstawiono przypadek 63-letniej pacjentki leczonej anastrozolem z powodu nowotworu piersi, u której w tracie chemioterapii doszło do rozwoju nadciśnienia tętniczego. U pacjentki przyjmującej inhibitor aromatazy w ramach leczenia onkologicznego poza tym nie doszło do rozwoju innych schorzeń układu sercowo-naczyniowego. Po włączeniu pięciu leków hipotensyjnych uzyskano prawidłowe wartości ciśnienia tętniczego.

Słowa kluczowe: nadciśnienie tętnicze, hormonoterapia, rak piersi, dyslipidemia

Folia Cardiologica 2017; 12, supl. B: B23-B25

\section{Wstęp}

U pacjentów z nowotworem często stwierdza się nadciśnienie tętnicze. Częstość i stopień zaawansowania nadciśnienia zależą między innymi od wieku pacjenta, wcześniejszego występowania schorzeń układu sercowo-naczyniowego, rodzaju nowotworu, rodzaju i dawki chemioterapeutyku oraz schematu dawkowania [1, 2].

\section{Opis przypadku}

Kobieta w wieku 63 lat, leczona anastrozolem z powodu nowotworu gruczołu piersiowego (rozpoznanie w 2014 r., operacja oszczędzająca oraz następcza radioterapia), zgłosiła się na szpitalny oddział ratunkowy z powodu wysokich wartości ciśnienia tętniczego (RR) wynoszących 202/100 mm Hg. Ponadto zgłaszała ból i zawroty głowy oraz zaburzenia widzenia. Z tego powodu wykonano u niej badanie metodą tomografii komputerowej głowy, w którym uwidoczniono rozlane obszary zmian naczyniopochodnych w istocie białej obu półkul mózgu oraz w odnogach przednich torebki wewnętrznej. Konsultujący neurolog nie stwierdził odchyleń w badaniu neurologicznym.

Na szpitalnym oddziale ratunkowym pacjentka otrzymała $50 \mathrm{mg}$ kaptoprilu oraz $80 \mathrm{mg}$ furosemidu dożylnie, uzyskując obniżenie wartości RR. By ustalić leczenie, chorą przyjęto do kliniki kardiologii inwazyjnej.

Po uzupełnieniu wywiadu okazało się, że podwyższone wartości ciśnienia tętniczego występowały u chorej od mniej więcej 3 miesięcy, a od około tygodnia codziennie przekraczały 150/100 mm Hg. Pacjentka do czasu 
hospitalizacji nie leczyła się z powodu schorzeń układu sercowo-naczyniowego, nie poddawano jej również żadnym badaniom obrazowym (elektrokardiograficznemu [EKG] ani echokardiograficznemu [ECHO]), mimo stosowanej terapii anastrozolem.

Przy przyjęciu do kliniki spośród odchyleń w badaniu przedmiotowym u pacjentki stwierdzono jedynie podwyższone wartości ciśnienia tętniczego (150/90 mm $\mathrm{Hg}$ ). W badaniach laboratoryjnych wykazano natomiast zaburzenia gospodarki lipidowej (stężenie cholesterolu całkowitego $236 \mathrm{mg} / \mathrm{dl}$, stężenie cholesterolu frakcji LDL [low-density lipoprotein] $161 \mathrm{mg} / \mathrm{dl}$, stężenie cholesterolu frakcji HDL [high-density lipoprotein] 39 mg/dl, stężenie triglicerydów $137 \mathrm{mg} / \mathrm{dl}$ ) oraz podwyższoną wartość glikemii na czczo $(108 \mathrm{mg} / \mathrm{dl})$. Na podstawie wykonanych badań (prawidłowe wartości kreatyniny, aldosteronu i wskaźnika aldosteronowo-reninowego, prawidłowe rytm dobowy kortyzolu oraz wydalanie metoksykatecholamin w dobowej zbiórce moczu, prawidłowe stężenie hormonów tarczycy) wykluczono wtórne przyczyny nadciśnienia tętniczego. W EKG nie stwierdzono cech niedokrwienia mięśnia sercowego ani przerostu ścian lewej komory. W badaniu ECHO serca uwidoczniono niepowiększone jamy serca, nieznacznie pogrubiały mięsień przegrody międzykomorowej, prawidłową kurczliwość ścian lewej komory (frakcja wyrzutowa [EF, ejection fraction] 60\%) i wolnej ściany prawej komory (skurczowy ruch płaszczyzny pierścienia trójdzielnego [TAPSE, tricuspid annular plane systolic excursion] $20 \mathrm{~mm}$ ) oraz zaburzenia funkcji rozkurczowej 1. stopnia. W badaniu EKG metodą Holtera zarejestrowano wstawki częstoskurczu przedsionkowego o maksymalnej częstości komór 146/min; nie wykazano bradykardii ani pauz. W ultrasonograficznym (USG) badaniu doplerowskim tętnic szyjnych nie stwierdzono istotnych hemodynamicznie zwężeń w tętnicach szyjnych. Konsultujący chorą okulista stwierdził angiopatię nadciśnieniową II stopnia.

Początkowo u pacjentki włączono ramipril w dawce $10 \mathrm{mg}$, amlodipine w dawce $5 \mathrm{mg}$, bisoprolol w dawce $10 \mathrm{mg}$, atorastatynę w dawce $40 \mathrm{mg}$ oraz kwas acetylisalicylowy w dawce $75 \mathrm{mg}$. Jednak ze względu na niedostateczną kontrolę ciśnienia tętniczego chora kilkakrotnie podczas hospitalizacji wymagała modyfikacji farmakoterapii. Ostatecznie podczas stosowania następującej farmakoterapii: telmisartan w dawce $80 \mathrm{mg}$, amlodipina w dawce $10 \mathrm{mg}$, indapamid w dawce $2,5 \mathrm{mg}$, bisoprolol w dawce $5 \mathrm{mg}$, w pomiarach wykonywanych podczas wizyty lekarza uzyskano ciśnienie tętnicze poniżej 140/90 mm Hg.

W celu oceny kontroli ciśnienia tętniczego podczas całej doby wykonano 24-godzinne monitorowanie ciśnienia (ABPM, ambulatory blood pressure monitoring). W ABPM zarejestrowano w czasie dnia średnie ciśnienie tętnicze 127/72 mm Hg, w nocy - 133/79 mm Hg, średnie wczesnoranne ciśnienie tętnicze - 120/71 mm Hg, w trakcie dnia odsetek ciśnienia skurczowego nie mniejszego niż 140 mm Hg wynosił 24,1\%, w nocy ciśnienie skurczowe miało wartość $125 \mathrm{~mm} \mathrm{Hg}$ lub więcej, odsetek ciśnienia rozkurczowego większego lub równego 80 mm Hg wynosił 46,7\%; nie zarejestrowano fizjologicznego obniżenia RR w godzinach nocnych (non-dipper). Stosując $80 \mathrm{mg}$ telmisartanu, $20 \mathrm{mg}$ nitrendipiny, $25 \mathrm{mg}$ hydrochlorotiazydu, $4 \mathrm{mg}$ doksazosyny, $5 \mathrm{mg}$ bisoprololu i $40 \mathrm{mg}$ atorwastatyny uzyskano dobrą kontrolę ciśnienia tętniczego. Podczas hospitalizacji u pacjentki wykonano doustny tekst tolerancji glukozy (OGTT, oral glucose tolerance test), na podstawie którego rozpoznano cukrzycę typu 2 . Włączono metforminę doustnie $(2 \times 500 \mathrm{mg})$ i zalecono dalszą kontrolę w poradniach diabetologicznej i dietetycznej. Podczas kontrolnej wizyty w poradni przyklinicznej, która odbyła się 3 miesiące po hospitalizacji, u chorej stwierdzono prawidłową kontrolę ciśnienia tętniczego w warunkach domowych. Kontrolny lipidogram wykazał istotne zmniejszenie wartości parametrów gospodarki lipidowej (stężenie cholesterolu całkowitego 178 mg/dl, stężenie cholesterolu frakcji LDL 119 mg/dl). Zalecono kontynuację farmakoterapii.

\section{Omówienie}

Jednymi z chemioterapeutyków stosowanych w leczeniu raka piersi są leki hormonalne. Terapia ukierunkowana na receptory estrogenowe i progesteronowe wpływa na występowanie schorzeń układu sercowo-naczyniowego, modyfikuje czynniki ryzyka chorób serca oraz zwiększa ryzyko powikłań zakrzepowo-zatorowych. Omawiana pacjentka przyjmowała wysoce selektywny niesteroidowy inhibitor aromatazy - anastrozol. Jego działanie blokuje kompleks enzymatyczny aromatazy, w wyniku czego nie dochodzi do przemiany androstendionu do estronu, co z kolei upośledza tworzenie estradiolu. Z fizjologicznego punktu widzenia wydaje się, że obniżenie stężenia estrogenów prowadzi do zwiększenia ryzyka chorób układu sercowo-naczyniowego. W badaniu ATAC (Arimidex, Tamoxifen, Alone or in Combination) [3] w 5-letniej obserwacji obejmującej kobiety z wczesnym rakiem piersi leczone anastrazolem u 4\% stwierdzono chorobę niedokrwienną serca, u 9\% - hipercholeterolemię, u 11\% rozwinęło się nadciśnienie tętnicze, u $2 \%$ wystąpił udar mózgu, natomiast u 3\% - epizody zakrzepowo-zatorowe. Należy jednak podkreślić, że wpływ terapii hormonalnej raka piersi na parametry gospodarki lipidowej nie jest jednoznaczny i nie udowodniono jego związku z ryzykiem powikłań sercowo-naczyniowych [4]. Zważywszy na niebezpieczeństwo wystąpienia tych powikłań, każda pacjentka przyjmująca leki z tej grupy powinna być dodatkowo otoczona opieką kardiologiczną i poddana badaniom EKG, ECHO oraz pomiarom ciśnienia tętniczego zarówno przed terapią, jak i w jej trakcie. Pacjentki powinny mieć świadomość ryzyka wystąpienia powikłań, co w sytuacji obecności podwyższonego ciśnienia tętniczego 
skłoniłoby je do szybszej wizyty u lekarza i mogłoby zapobiec wystąpieniu powikłań, do których doszło u omawianej chorej (nadciśnienie tętnicze, zaburzenia gospodarki lipidowej oraz zmiany naczyniopochodne w ośrodkowym układzie nerwowym). Niestety, przypadek omawianej pacjentki nie umożliwia jednoznacznego określenia, czy występujące u niej nadciśnienie tętnicze jest wtórne do przyjmowanego leku czy też pierwotne. Biorąc pod uwage jej wiek (63 lata), w którym najczęściej rozwija się nadciśnienie tętnicze, oraz fakt przyjmowania leku, który może wpłynąć na rozwój nadciśnienia, należałoby oba te czynniki przyjąć za etiologię schorzenia u opisanej chorej.

\section{Konflikt interesów}

Nie zgłoszono.

\section{Abstract}

We present the case of 63-year-old patient with breast cancer treated with anastrozole, in whom the development of arterial hypertension during chemotherapy occurred. The patient using an aromatase inhibitor for the oncological treatment, did not experience the development of other diseases of the cardiovascular system besides elevated blood pressure. After inclusion of five antihypertensive drugs normal blood pressure was achieved.

Key words: arterial hypertension, hormone therapy, breast cancer, dyslipidemia

Folia Cardiologica 2017; 12, supl. B: B23-B25

\section{Piśmiennictwo}

1. Zamorano JL, Lancellotti P, Rodriguez-Muñoz D, et al. [2016 ESC Position Paper on cancer treatments and cardiovascular toxicity developed under the auspices of the ESC Committee for Practice Guidelines]. Kardiol Pol. 2016; 74(11): 1193-1233, doi: 10.5603/kp.2016.0156, indexed in Pubmed: 27910076.

2. Red Ty, Narkiewicz K, Gaciong Z, et al. Zasady postępowania w nadciśnieniu tętniczym - 2015. Nadciśnienie Tętnicze. 2015; 1(1): $1-70$.
3. Buzdar A, Howell A, Cuzick J, et al. Arimidex, Tamoxifen, Alone or in Combination Trialists' Group. Comprehensive side-effect profile of anastrozole and tamoxifen as adjuvant treatment for early-stage breast cancer: longterm safety analysis of the ATAC trial. Lancet Oncol. 2006; 7(8): 633-643, doi: 10.1016/S1470-2045(06)70767-7, indexed in Pubmed: 16887480.

4. Wojtacki J, Lesniewski-Kmak K, Pawlak W, et al. Anastrozole therapy and lipid profile: an update. Eur J Cancer Suppl. 2004; 2(3): 142, doi: 10.1016/s1359-6349(04)90900-7. 